\title{
Caddo Ceramics from an Early 18th Century Spanish Mission in East Texas: Mission San Jose de los Nasonis (41RK200)
}

Timothy K. Perttula

Heritage Research Center, Stephen F. Austin State University

Bill Young

P. Shawn Marceaux

Follow this and additional works at: https://scholarworks.sfasu.edu/ita

Part of the American Material Culture Commons, Archaeological Anthropology Commons, Environmental Studies Commons, Other American Studies Commons, Other Arts and Humanities Commons, Other History of Art, Architecture, and Archaeology Commons, and the United States History Commons

Tell us how this article helped you.

This Article is brought to you for free and open access by the Center for Regional Heritage Research at SFA ScholarWorks. It has been accepted for inclusion in Index of Texas Archaeology: Open Access Gray Literature from the Lone Star State by an authorized editor of SFA ScholarWorks. For more information, please contact cdsscholarworks@sfasu.edu. 


\section{Caddo Ceramics from an Early 18th Century Spanish Mission in East Texas:}

Mission San Jose de los Nasonis (41RK200)

\section{Creative Commons License}

\section{(c) (1) \&}

This work is licensed under a Creative Commons Attribution-NonCommercial 4.0 International License 


\title{
Caddo Ceramics from an Early 18th Century Spanish Mission in East Texas: Mission San Jose de los Nasonis (41RK200)
}

\author{
Timothy K. Perttula, Bill Young, and P. Shawn Marceaux
}

\section{INTRODUCTION}

Mission San Jose de los Nasonis (4IRK200) and two contemporaneous Nasoni Caddo sites (41RK191 and 41RK197) were located by Mr. Bill Young more than 25 years ago in the southern part of Rusk County, Texas (Figure 1) after the general area of the site had been cleared of timber. The mission site covers ca. 6.6 acres of an upland ridge along a small tributary to the Angelina River (Figure 2); the ridge projects into the Angelina River floodplain. The topographic setting of Mission San Jose conforms in all particulars to the settings of other known mission sites established among the Caddo (Corbin 1989:273): small hills adjacent to a floodplain, next to a strcam, with the hills "lower extensions of more extensive upland areas." Corbin (1989:273) also notes that these missions "were located within the area of the local dispersed Caddoan village. none of the locations are places suited to support the Indianbased community that the Spanish hoped to entice to the location."

This mission was established as one of six different missions by the Spanish in 1716 during their second attempt (the first being in 1690-1691) to establish a religious and political presence among the Caddo peoples (Corbin 1989:269-270) in East Texas, specifically to minister to the Nasoni Caddo living in the area. Mission San Jose de los Nasonis was formally established on July 10, 1716 (Tous 1930). Father Espinosa and Captain Don Domingo Ramon, the leader of the expedition, had noted that there were many Hasinai Caddo ranchos in the general area along with arroyos of water and good places for settlement (Foik 1999:147). Both Nasoni and Nacono Caddo were then living in this area of the Angelina river.

An expedition to bring supplies to the East Texas missions was led by Governor Martin de Alaracon in 1718, and the expedition visited Mission San Jose de los Nasonis in November of that year (see Celiz.
1935; Foster 1995:139, 2008:209). Celebrations were held by the missionaries and the local Caddo when the governor arrived. According to the diary of Father Celiz (1935), 3I Caddo had been baptized at Mission San Jose de los Nasonis. Shortly thereafter, in 1719, Mission San Jose was abandoned due to conflicts between the colonial Spanish and French governments (Castaneda 1936:115), and the Spanish withdrew from the region.

The mission was reestablished in August 1721 by the Governor of Texas, Marques de San Miguel de Aguayo (Forrestal 1999; Foster 1995, 2008), along with the five other missions and two presidios that had first been established a few years before. When Aguayo reached Nasoni on August 12th, according to Father Pena, "The Indians of this mission... welcomed him with great demonstration of joy" (Forrestal 1999:198). After restoration of the mission, 300 Nasoni Caddo assembled bcfore the governor as he invested the local Caddo leader (or captain, otherwise known as caddi in the Caddo language) with his insignia of office (a silver-headed baton). Aguayo then:

\begin{abstract}
clothed the captain in a complete suit of Spanish cloth and of the Spanish style, clothed all the rest in the same kind of garments as he had distributed at the other missions, and, as he had done at other pucblos, gave to the missionary Fray Benito Sanchez clothing for the Indians who at the lime were absent guarding their cornfields and houses. The natives, 300 of whom were clothed here, were happy, and all day long they brought pumpkins, watermelons, ears of corn and pinole (Forrestal 1999: 198-199).
\end{abstract}

Along with the gifts of clothing, Aguayo likely also distributed other gifts to the Nasoni, as he had done at Mission Concepcion the day before to the Tejas Caddo as well as some visiting Cadodachos 


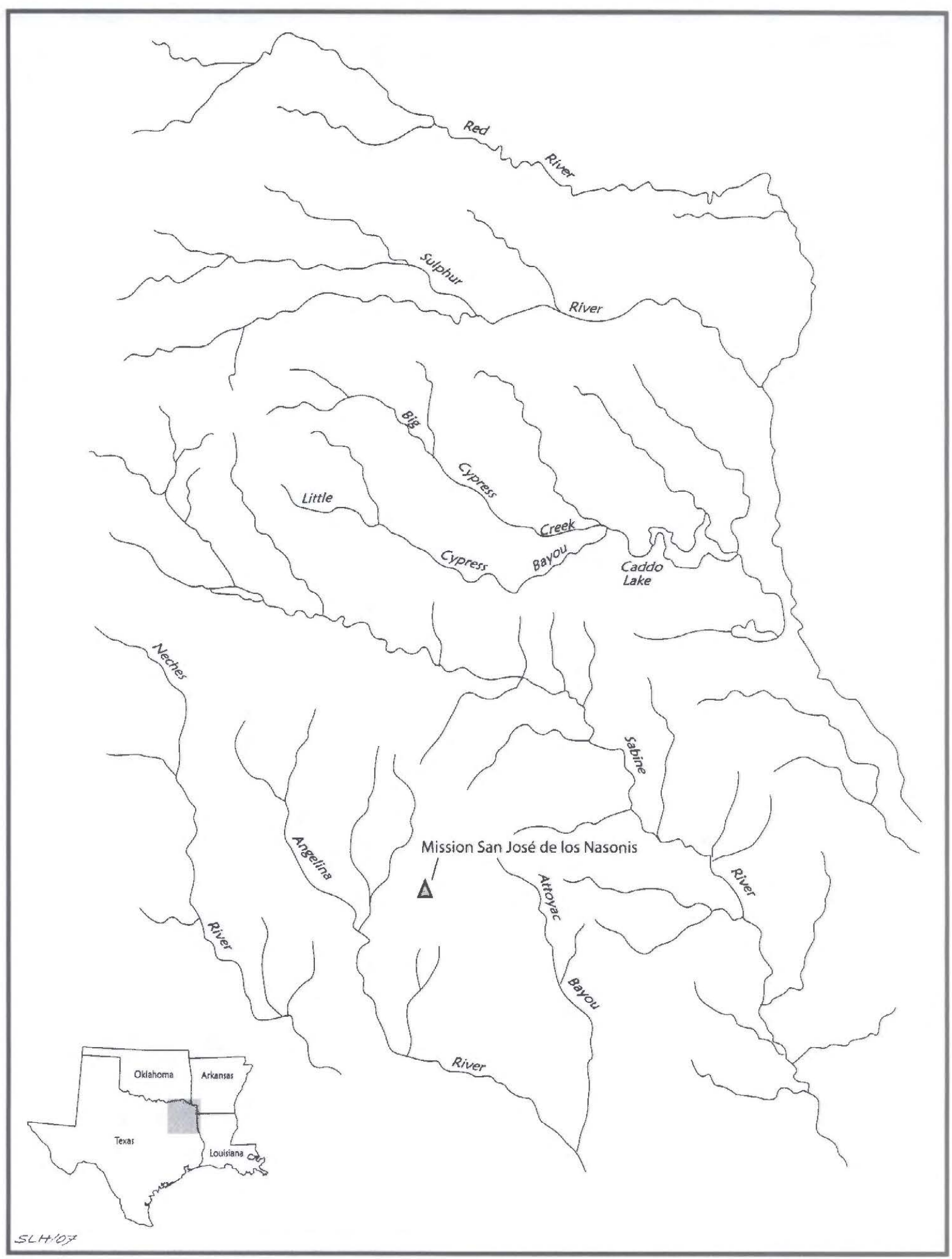

Figure 1. The general location of Mission San Jose de los Nasonis in the Angelina River basin of East Texas. 


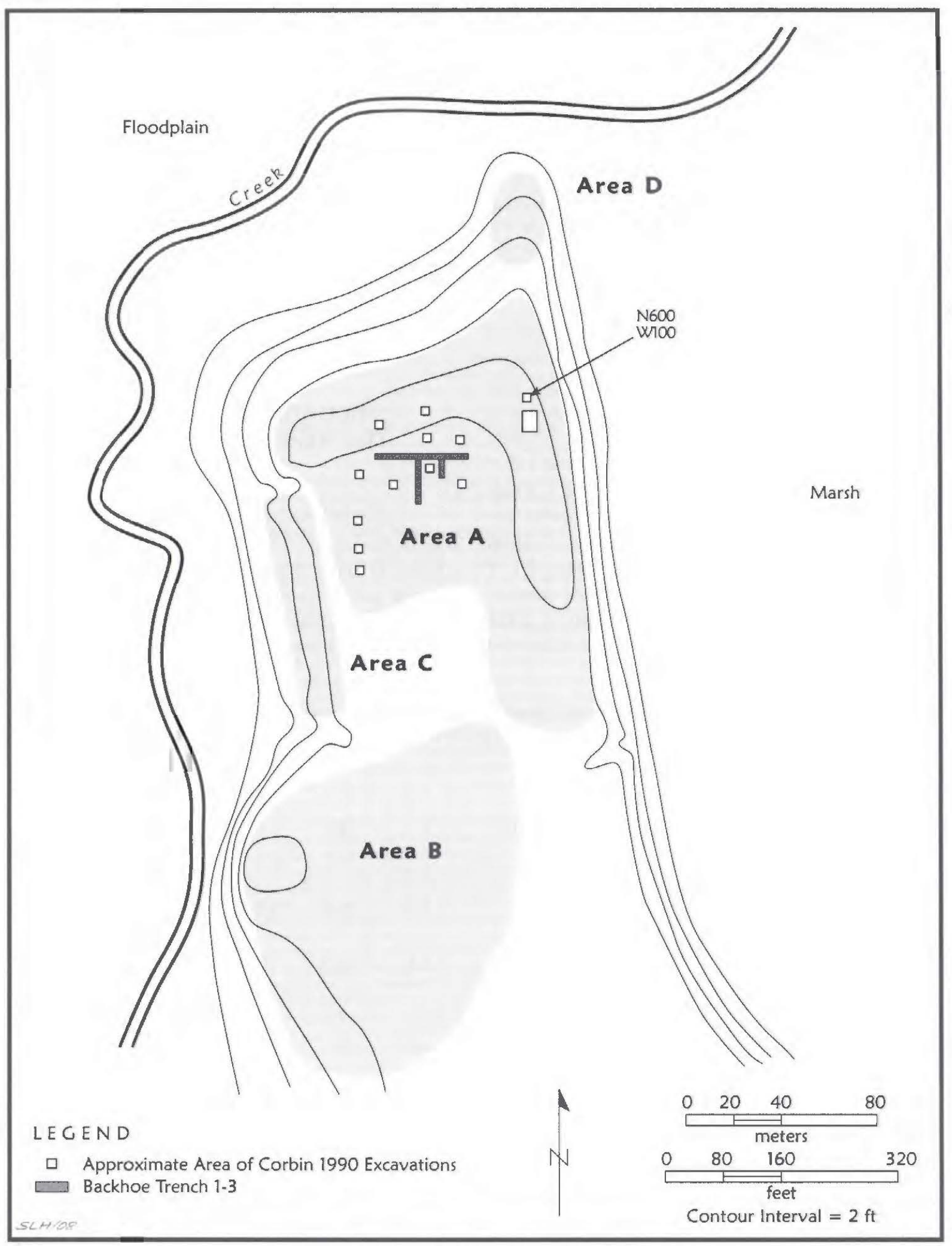

Figure 2. Collection areas A-D at Mission San Jose de los Nasonis (41RK200). 
from the Red River. These would have included "knives, combs, awls, scissors, mirrors, belduques [large knives], chain-links, chocomites, belts, necklaces, earrings, glass beads, and finger rings" (Forrestal 1999:198)

Mission San Jose de los Nasonis was finally and permanently abandoned in 1730 , along with Mission San Francisco de los Tejas on San Pedro Creek, Mission Concepcion, and Presidio Dolores de los Tejas. The latter two had been reestablished on the Angelina River, ahout seven leagues (ca. 18 milcs) southwest of Mission San Jose de los Nasonis.

Mr. Young acquired substantial collections of Caddo artifacts and European goods at the mission (from Areas A-D) from surface collections and metal detector surveys (see Figure 2); thcre also is a considerable Late Paleoindian and Archaic lithic assemblage. His metal detector survey defined four specific conccntrations of European metal goods over a 3.8 acre part of Area $\mathrm{A}$ and $\mathrm{C}$, and these concentrations, along with aboriginal ceramic artifacts, occur around an open area (mission courtyard or plaza?) with few noticeable artifacts. These concen trations of metal goods probably represent the areas of at least four or five mission structures. Hc also obtained surface collections from the two contemporaneous Nasoni Caddo sites.

Mr. Young made those collections as ailable for study in 2006, and this article is a summary of the Caddo ceramics in the Mission Nasonis collections. In 1990, Dr. James E. Corbin of Stephen F. Austin State University (SFASU) and Dr. Kathleen Gilmore of the University of North Texas conducted limited excavations in Area $\mathrm{A}$ at the mission site, but these excavations have nevcr been published. More than 930 Caddo ceramic sherds were recovered in that work, and are curated at SFASL; the separate analysis of these ceramic artifacts is underway.

\section{CADDO MATERIAL CLLTLRE AT THE MISSION: NASONI CADDO CERAMIC'S}

A total of 8584 aboriginal Caddo ceramic sherds are in the Young collection from Mission San Jose de los Nasonis, along with 559 sherds from the two nearby Nasoni Caddo sites (Tahle 1). At the mission. the highest numbers of sherds are from Area A (see Figure 2), followed in order by Areas $\mathrm{C}$ and $\mathrm{B}$.

'lable 1. Aboriginal Caddo Ceramics from Mission San Jose de los Nasonis (41RK200) and contemporaneous Nasoni Caddo sites (41RK191 and 41RK197).

\begin{tabular}{|c|c|c|c|c|c|c|c|}
\hline \multirow{3}{*}{$\begin{array}{l}\text { Ware and } \\
\text { Decorative } \\
\text { Method }\end{array}$} & \multirow{3}{*}{$4 \mid \mathrm{RK} 191$} & \multirow{3}{*}{$41 \mathrm{RK} 197$} & \multirow{3}{*}{ A } & \multirow{3}{*}{$\mathrm{B}$} & \multicolumn{2}{|c|}{ 41RK200) } & \multirow{3}{*}{ Gen. } \\
\hline & & & & & $\mathrm{C}$ & $\mathrm{D}$ & \\
\hline & & & & & & & \\
\hline Plain ware & $37.3^{*}$ & 37.7 & 74.8 & 63.8 & 61.4 & 62.0 & 75.7 \\
\hline Utility ware & 59.6 & 52.2 & 23.1 & 28.9 & 30.3 & 38.1 & 21.6 \\
\hline Brushed rim/body & 47.5 & 42.2 & 15.6 & 24.7 & 23.3 & 24.6 & 14.1 \\
\hline Brushed-appliqued body & 0.0 & 0.0 & 0.0 & 0.0 & 0.0 & 0.0 & + \\
\hline Brushed-Punctated- & & & & & & & \\
\hline Incised rim & 0.3 & 0.0 & 0.0 & 0.0 & 0.0 & 0.0 & 0.0 \\
\hline Brushed-punctated & & & & & & & \\
\hline $\mathrm{rim} / \mathrm{body}$ & 1.7 & 1.5 & 0.1 & 0.6 & 0.0 & 0.4 & 0.2 \\
\hline Brushed-Incised body & 0.3 & 1.0 & 0.2 & 0.6 & 0.0 & 0.0 & 0.4 \\
\hline Appliqued & 0.0 & 0.0 & + & 0.0 & 0.2 & 0.4 & 0.1 \\
\hline Appliqued- & & & & & & & \\
\hline Punctated body & 0.0 & 0.0 & + & 0.0 & 0.0 & 0.0 & 0.0 \\
\hline Punctated rim/body & 1.4 & 2.5 & 1.9 & 2.0 & 0.7 & 1.9 & 1.6 \\
\hline Incised-Punctated $\mathrm{rim} / \mathrm{body}$ & 0.3 & 0.5 & 0.2 & 0.0 & 0.5 & 0.4 & 0.3 \\
\hline
\end{tabular}


Table 1. (Continued)

\begin{tabular}{lccccccc}
\hline $\begin{array}{l}\text { Ware and } \\
\text { Deeorative } \\
\text { Method }\end{array}$ & 41RK191 & 41 RK197 & A & B & C & D & Gen. \\
\hline $\begin{array}{l}\text { Incised rim/body } \\
\text { Neck banded rin }\end{array}$ & 7.8 & 4.5 & 5.1 & 0.8 & 5.6 & 10.4 & 4.9 \\
& 0.3 & 0.0 & 0.0 & 0.2 & 0.0 & 0.0 & + \\
Fine ware & 3.4 & 10.0 & 2.0 & 7.2 & 8.5 & 0.0 & 2.9 \\
Engraved rim/body & 3.1 & 10.0 & 2.0 & 7.0 & 8.5 & 0.0 & 2.9 \\
Engraved-Punctated body & 0.0 & 0.0 & 0.0 & 0.2 & 0.0 & 0.0 & 0.0 \\
Red-slipped body & 0.3 & 0.0 & 0.0 & 0.0 & 0.0 & 0.0 & 0.0 \\
\hline Totals & 360 & 199 & 2426 & 498 & 559 & 260 & 4841 \\
\hline
\end{tabular}

*percentage; $\mathrm{t}=$ trace

The Nasoni Caddo ceramics found at the mission-presumably in areas where they were used and discarded by missionaries and soldiers--include plain wares, utility wares, and engraved and slipped fine ware vessels. Brushed and incised vessel sherds, as well as plain sherds from undecorated vessels and from the lower parts of decorated vessels, dominate the ceramic assemblage at the mission. Fine wares comprise only between $2-8.5 \%$ in any one intramission area (see Table 1). ${ }^{1}$

Common decorative elements among the Mission San Jose de los Nasonis utility wares and fine wares are illustrated in Figures 3 and 4. Jars had brushed, brushed-punctated, brushed-appliqued, and brushed-incised decorations on both rim and vessel bodies, and there are identifiable motifs that feature opposed incised, opposed incised-tool punctated, diagonal incised, and vertical incised panels, as well as vertical brushing on bodies with tool punctates pushed through the brushing and horizontal brushing on vessel bodies below a row of tool punctates (probably placed along the rim-body juncture) (Figure 3a-g).

The most recognizable engraved elements at the mission and the Nasoni Caddo sites include ticked horizontal and curvilinear lines from Patton Engraved vessels (Figure $4 b-c, j, 1$ )), and later forms of Poynor Engraved (var. Cook and var. Blackburn, see Perttula 2008) also appear to be present in the mission assemblage (Figure 4f, $\mathrm{k}, \mathrm{m}$ ). Among the more distinctive engraved decorations at the mission are a number of sherds with closely-spaced cross-hatched filled panels on the rim of carinated bowls and a sherd or two with cross-hatched triangles and ovals (Figure $4 \mathrm{a}, \mathrm{i}$ ). Sherds with hatched engraved ladders (Figure $4 \mathrm{~h}$ ) may be from Hume Engraved bottles.

The aboriginal ceramics from the two Nasoni Caddo sites are a good bit different when compared to the assemblage of ceramic vessel sherds from the mission (Table 2). The Nasoni Caddo sites have overall high proportions of decorated sherds (P/DR values of $0.59-0.60: 1$ ), particularly brushed sherds, as well as more utility ware vessel sherds, especially brushed-punctated, punctated, and incised rim sherds.

Conversely, at the mission, there are more plain wares-as reflected in the P/DR values that range from 1.59:1 to 3.11:1 by area-as well as engraved fine wares. Although the overall percentage of brushed vessel sherds is at least two times lower at the mission compared to the Nasoni Caddo sites, the proportion of brushed vessels in the decorated sherds is not that different from what has been documented at the former sites (i.e., $60-80.6 \%$ versus $71.8-79.2 \%$ ). What might account for these differences? Several possibilities come to mind, including (a) temporal differences between the mission occupation and the non-mission Nasoni Caddo settlements; (b) differential preferences by Spanish missionaries and soldiers for only certain kinds of Nasoni Caddo vessels; (c) intra- and inter-site functional differences in pottery use, consumption, and discard; and (d) systematic collection biases. These 


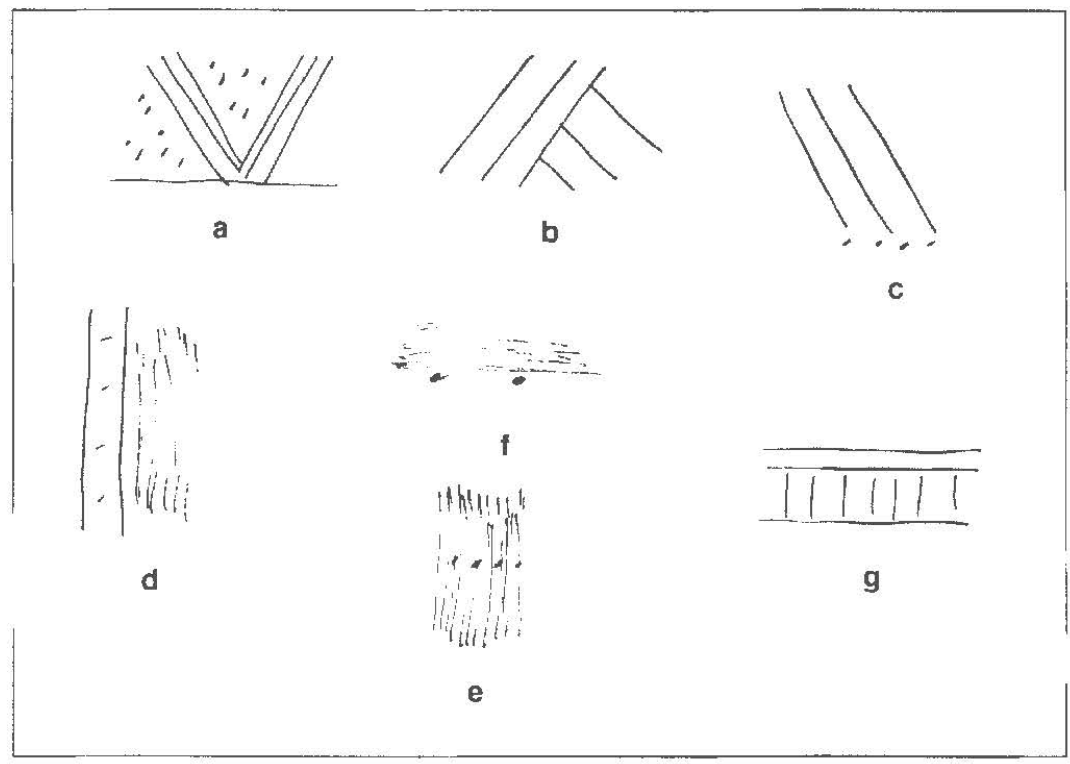

Figure 3. Selected decorative elements in the Mission Nasonis utility wares: a, c, incised-punctated; b, g, incised; d, appliqued-brushed; e-f, brushed-punctated.

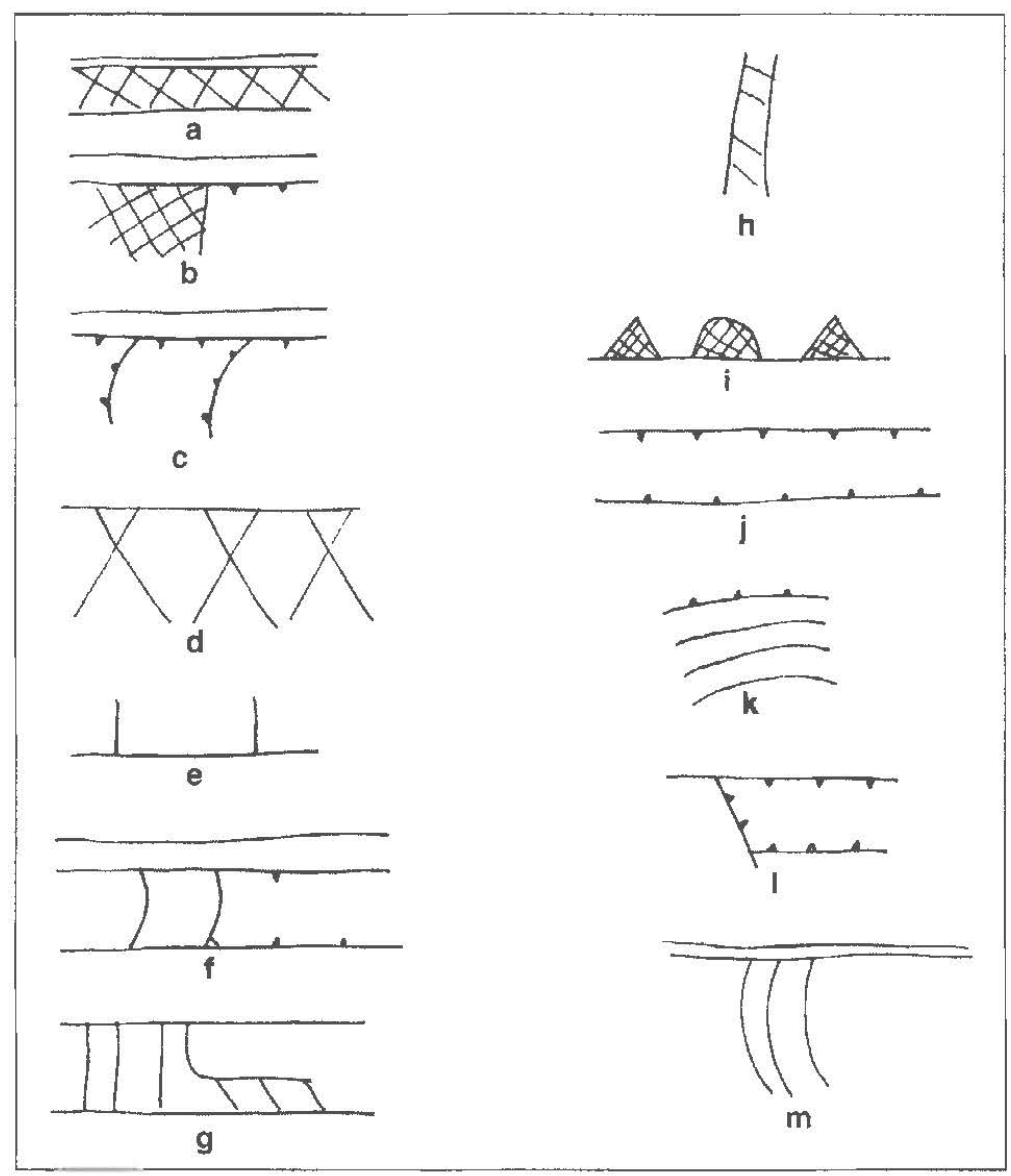

Figure 4. Selected decorative elements in the Mission Nasonis engraved fine ware sherds: a, cross-hatched panel: b, cross-hatched panel and tick marks (Patton Engraved); c, j, l, Patton Engraved; d, cross-hatched; e, horizontal and vertical engraved lines; f, k, m. Poynor Engraved; g, vertical and curvilinear panels; h, hatched ladder; i, cross-hatched triangles and ovals. 
Table 2. Basic Distinctions or Trends in the Character of Nasoni Caddo Ceramic Sherd Assemblages.

\begin{tabular}{lcc}
\hline Prevalent decorative methods & Nasoni sites & Mission Nasoni \\
\hline Plain wares & & + \\
Appliqued body & & + \\
Punctated body & & + \\
Incised-punctated body & & + \\
Incised body & + & + \\
Engraved rim/body & + & \\
Engraved-punctated body & + & \\
Fine wares & + & \\
Plain rim & + & \\
Brushed rim/body & + & \\
Brushed-punctated body & + & \\
Punctated rim & + & \\
Incised rim & & \\
Utility wares & & \\
Red slipped & $0.59-0.60: 1$ & $60.0-80.6$ \\
P/DR & $71.8-79.2$ & \\
\% B/DR &
\end{tabular}

$+=$ highest proportions in the various assemblages

$\mathrm{P} / \mathrm{DR}=$ plain/decorated sherd ratio

$\% \mathrm{~B} / \mathrm{DR}=$ percentage of brushed sherds divided by all the decorated sherds

and other possibilities may be evaluated if and when further controlled excavations are conducted at the site, or when the detailed analysis is completed of the ceramic sherds from the Area A excavations by Dr. James E. Corbin.

The Mission Nasonis Caddo ceramics are tempered primarily with burned bone and/or grog, either as the sole additive or in combinations with one another, or with hematite or charred organics:

$\begin{array}{lr}\text { Bone temper } & 38.7 \% \\ \text { Bone-grog temper } & 17.5 \% \\ \text { Bone-hematite temper } & 2.1 \% \\ \text { Bone-organics } & 1.6 \% \\ \text { Bone-grog-organics-temper } & 1.0 \% \\ \text { Grog temper } & 33.5 \% \\ \text { Grog-hematite temper } & 2.6 \% \\ \text { Grog-hematite-bone temper } & 0.5 \% \\ \text { Grog-organics } & 1.0 \% \\ \text { Grog-sandy paste } & 1.5 \%\end{array}$

For the assemblage as a whole (considering that many of the sherds had more than one kind of temper), more than $61 \%$ of the sherds analyzed in detail from Mission Nasoni have bone as one of the temper additives to the ceramic vessels used and broken at the mission. Almost $57 \%$ have some grog temper, but only $5.2 \%$ of the sherds have hematite aplastics, either mixed with grog or bone. ${ }^{2}$ The clays chosen for the manufacture of the pottery vessels brought by the Nasoni to the mission had clay or silty pastes, with almost no use of naturally sandy clays; only $1.5 \%$ of the vessel sherds analyzed in detail from the Bill Young collection have a sandy paste.

The dominance of bone-tempered pottery at Mission San Jose de los Nasonis, along with the substantial amount of brushed pottery, is good evidence that the Nasoni Caddo ceramic tradition arose in the area between the Sabine River to the north and east and the Angelina and Attoyac basins to the south and west. A brushed bone-tempered cast to the Caddo ceramics in this area can be traced back to as early as ca. A.D. $1200-1250$ in this part of East Texas (Perttula 2002:369-370).

Information on firing conditions of a sample of sherds $(n=194)$ from the mission indicate that most of the sherds come from vessels that were fired in a reducing environment $(86.1 \%)$. Of these, $51 \%$ 
came from vessels that were removed from the fire to cool down, leaving a thin oxidized band visible on one or both vessel surfaces (Teltser 1993:Figure $2 \mathrm{f}-\mathrm{h})$. The remainder of the analyzed sherds are from vessels that were either oxidized during firing $(6.2 \%$, Teltser 1993:Figure $2 a)$, or were not fired at a sufficiently hot enough temperature or for a long enough duration to completely oxidize the paste $\left(7.7 \%\right.$, see Teltser 1993:Figure 2c-e). ${ }^{3}$

\section{CONCLUSIONS}

The artifact collection from Mission San Jose de los Nasonis (41RK200) contains a wealth of information about the type of material goods found on an early $18^{\text {th }}$ century Spanish mission in East Texas Caddo country, most notably the range of available European goods brought by the missionaries and soldiers or brought to the mission on re-supply treks. Of particular significance in the Mission San Jose de los Nasonis collection is the abundance of Nasoni Caddo ceramics on the mission, which is strong evidence that the missionaries and soldiers interacted with the nearby Nasoni Caddo, who clearly must have supplied the Europeans with hand-made plain and decorated pottery for their use, and probably also supplied them with food stuffs, hides, pelts, and bear grease, among other local and familiar resources. The predominance of bone-tempered Caddo wares at the mission, as well as the dominance of brushed utility wares and Patton and Poynor Engraved fine wares, indicate that the Nasoni Caddo potters living around the mission between 1716-1730 were part of a spatially broad and temporally long-lasting (beginning ca. A.D. 1250) Caddo ceramic tradition in the Neches, Angelina, Attoyac, and middle reaches of the Sabine river basins.

\section{END NOTES}

1. Plain wares account for $58.3 \%$ of the sherds from the Area A excavations led by Corbin, while utility wares comprise $37.5 \%$ of this particular sample; most of these are brushed body sherds $(31.2 \%)$ and incised body sherds (3.6\%). Fine wares comprise only $4.1 \%$ of the sherds from Corbin's excavations in Area $\mathrm{A}$ at the site.

2. In the Area A excavations, $74 \%$ of the sherds analyzed in detail $(n=281)$ have bone temper, either as the sole aplastic or in combination with grog, hematite, or charred organics. In this same sample, $41 \%$ have grog tempering, $17.9 \%$ have some amount of hematite temper (usually occurring in conjunction with burned bone), and $2.2 \%$ have charred organics in the paste.

3. In Corbin's Area A excavations, $76.7 \%$ of the sherds are from vessels that had been fired in a reducing environment, and most of them were subsequently cooled in the open air.

\section{REFERENCES CITED}

Castaneda, C. E.

1936 Our Catholic Heritage in Texas, 1519-1936, Volume 2: The Mission Era: The Winning of Texas, 16931731. Von Boeckmann-Jones, Austin.

Celiz, F.

1935 Diany of the Alarcon Expedition into Texas, 17181719. Edited and translated by F. L. Hoffman. Quivira Society, Los Angeles.

Corbin, J. E.

1989 Spanish-Indian Interaction on the Eastern Frontier of Texas. In Columbian Consequences, Volume I: Archaeological and Historical Perspectives on the Spanish Borderlands West, edited by D. H. Thomas, pp. 269-276. Smithsonian Institution Press, Washington, D.C.

Foik, P. J.

1999 Captain Don Domingo Ramon's Diary of his Expedition into Texas in 1716. In Wilderness Mission; Preliminary Studies of the Texas Catholic Historical Society II, edited by J. F. de la Teja, pp. 129-148. Studies in Southwestern Catholic History No. 2. Texas Catholic Historical Society, Austin.

Forrestal, P. P.

1999 Pena's Diary of the Aguayo Expedition. In Wilderness Mission: Preliminary Studies of the Texas Catholic Historical Society II, edited by J. F. de la Teja, pp. 161-214. Studies in Southwestern Catholic History No. 2. Texas Catholic Historical Society, Austin.

Foster, W. C.

1995 Spanish Expeditions into Texas, 1689-1768. University of Texas Press, Austin.

2008 Historic Native Peoples of Texas. University of Texas Press, Austin.

Perttula, T. K.

2008 The Ceramic Artifacts from the Lang Pasture Site (41AN38) and the Place of the Site within an Upper Neches River Basin Caddo Ceramic Tradition. MS on file, Archeological \& Environmental Consultants, LLC, Austin, and Coastal Environments, Inc., Baton Rouge. 
Perttula, T. K. (editor)

2002 Archeological Investigations at the Proposed Lake Naconiche, Nacogdoches County, Texas. 2 Vols. Report of Investigations No. 42. Archeological and Environmental Consultants, Austin.

Teltser, P. A.

1993 An Analytic Strategy for Studying Assemblage-Scale Ceramic Variation: A Case Study from Southeast Missouri. American Antiquity 58(3):530-543.
Tous, G.

1930 Ramon's Expedition: Espinosa's Diary of 1716. Preliminary Studies of the Texas Catholic Historical Sociery 1(No. 4):4-24. 